\title{
The Satisfaction Level Of Education Technology On Students' Learning Process
}

\author{
Siti Harijah Ramli; Nur Syazana Razali; Nur Afifah Abdullah \\ \{shijaramli@gmail.com, sharina@unikl.edu.my\} \\ Universiti of Kuala Lumpur Business School
}

\begin{abstract}
Educational technology has been used as students' learning process approach as a complement to the traditional method. The study aimed to measure the students' satisfaction level on the learning process of the four educational technology dimensions namely; (a) interactivity, (b) usefulness, (c) information quality (d) flexibility. This research used quantitative (survey questionnaire) method to test hypothesized relationships between the variables. Online questionnaires were distributed through convenience sampling method, among students from various University and about 105 questionnaires were collected. The result shows that the dimension of interactivity and usefulness are positively influence the level of satisfaction while information quality and flexibility indicate no relationships. In conclusion, this research has revealed the dimensions that need to be measured on the satisfaction level on student's learning process towards educational technology.
\end{abstract}

Keywords: satisfaction, educational technology, learning process, e-learning

\section{Introduction}

Educational technology has been around for many years and has become widely regarded as alternatives for a variety of educational contexts [1]. According to Barak \& Dori (2005), the internet is used as a source of scientific data and theoretical information and among its many applications, the web serves as a tool for integrating virtual model, creating learning communities, and designing new learning environment that results on the student's learning process satisfaction. Essentially, e-learning is an alternative way to teach and learn [3].

Education technology has been used widely among students nowadays. Research on educational technology showed the importance of it for student's continuance satisfaction, hence those involved in online learning should be concerned about increasing learning satisfaction. However, less attention has been focused on the level of satisfaction of the user which lead to differentiations in student's learning process [4], in term of interaction, usefulness, information quality, and flexibility. According to [1], argued despite the rapid growth of e-learning, it did not give assurance of an equivalent improvement in the quality of learning. This is important because level of satisfaction will have an impact on the student's learning experience and inter-related with self-efficacy, anxiety, and interactive learning environments [5]. Previously, this research has the similar researcher which has conducted by some researchers, such as in [6], [7], and [8] research. The research of [6] aimed to analyze 
teachers' perceptions on effectiveness of ICT integration to support teaching and learning process in classroom. Based on their analysis, the results indicate that ICT integration has a great effectiveness for both teachers and the students. Findings indicate that teachers' wellequipped preparation with ICT tools and facilities is one the main factors in success of technology-based teaching and learning. It was also found that professional development training programs for teachers also played a key role in enhancing students' quality learning. In additional, in study of [7] aimed to investigate the possible relationship between students' use of technology and their achievements in physiology courses at five health colleges of the University of Dammam. The finding of this study showed that this study observed a significant relationship between students' use of technology and their achievements in health colleges. The study also demonstrated that the most-used devices are laptops $(50 \%)$ and phones $(42 \%)$ followed by tablets $(7 \%)$ and desktop computers $(0.5 \%)$. This paper reports on the results of the survey, documenting what was revealed regarding how technology is used among students at the health colleges, as well as the important benefits on their achievements during physiology courses. Furthermore, a study conducted by [8] aimed to address this through a case study with pre-registration students using a virtual learning environment (VLE) to sup-plement their learning. The results of this study showed that most students were satisfied with the resources and that they facilitated knowledge acquisition. Thematic analysis from the focus groups resulted in five higher order themes: (1) Content quality, (2) Interaction and accessibility, (3) Learning goal alignment, (4) Satisfaction with resources and (5) Suggestions for the future. Learning analytics data revealed stu- dents accessed the resources predominantly before examination periods. There were statistically significant improvements in mean examination marks compared to the previous cohort.

Based on the background and the previous elated studies above, thus this research aims to measure the satisfaction of education technology on the student's current learning process. This study focuses on the context where education technology is used as a supplementary tool to enhance student learning process. This research measure the satisfaction of education technology based on student's experience. This research is an initial step toward measuring the satisfaction of student's usage on educational technology. The main objective is to determine the research is to fill up the mention above in the problem statement. According to the problem statement, the objective can be summarized: 1) to identify the relationship between the interactive educational technology and student's learning process. 2) to identify the relationship between the usefulness of using educational technology and student's satisfaction on learning process. 3) to identify the relationship between the information quality of educational technology and student's learning process. 4) to identify the relationship between the flexibility of educational technology and student's learning process.

\section{Methods}

This research is conducted through online platform, (Google form) utilizing the technology regarding the satisfaction of education technology on student's learning process. Questions are being adopted from past research made by previous researchers. This research used quantitative (survey questionnaire) method to test hypothesized relationships between the variables. The questionnaires are distributed to all colleges and universities students to get more accurate response accordingly. This is to clarify whether education technology has been effective among the students and measuring their satisfaction using the tools provided from 
the educational technology. For this survey, there are 118 respondents from different institutes that help to answer all the questions based on the given questionnaires in four days. The time taken to complete this questionnaire is approximately 10-15 minutes. There are 5 sections in the questionnaire, consist of student's satisfaction on learning process and education technology dimensions. After data screening, only 105 questionnaires were used for analysis due to the incorrect response. Five-point Likert scale that ranged from 1 = "very dissatisfied" to 5 = "very satisfied" were utilized. This research employed quantitative data for analysis. SPSS was used to compute the result from data collected.

\section{Results And Discussion}

In this study, Statistical Package for Social Sciences (SPSS) or SPSS is being used to analyse and calculate the data and to test the hypotheses. Student's satisfaction using educational technology is important as it enhance student's learning process. The data descriptive by SPSS that showing all the respondent's profile. The respondent are mostly degree students from IPTA and IPTS.

Table 1: Profile of survey respondents $(n=105)$

\begin{tabular}{llcc}
\hline Measure & Items & Frequency & Percentage (\%) \\
\hline Institution & IPTA & 39 & 37.1 \\
& IPTS & 66 & 62.9 \\
Program & Diploma & 12 & 11.4 \\
& Degree & 91 & 86.7 \\
& Others & 2 & 1.9 \\
Gender & Female & 58 & 55.2 \\
& Male & 47 & 44.8 \\
Usage & Rarely & 8 & 7.6 \\
& Frequently & 69 & 65.7 \\
& Occasionally & 28 & 26.7 \\
\hline
\end{tabular}

The respondents in this research were one-hundred and five $(\mathrm{N}=105)$ came from different institutions classified by IPTA, 39 respondents (37.1\%) and IPTS, 66 respondents (62.9\%). The respondents' program that are involved in this research are 12 respondents from Diploma (11.4\%), 91 respondents from Degree $(86.7 \%)$ and 2 respondents from others $(1.9 \%)$. The respondents consist of 58 female respondents $(55.2 \%)$ and 47 male respondents $(44.8 \%)$.

Table 2: Means and standard deviation (from 1 which means "very dissatisfied" to 5 which means "very satisfied")

\begin{tabular}{llcc}
\hline & \multicolumn{1}{c}{ Questions } & Mean & SD \\
\hline & Dimensions of student satisfaction & 4.0438 & .89011 \\
DV1 & Educational technology served my needs well & 4.0190 & .95052 \\
DV2 & Educational technology increased my interests in the subject & 3.9143 & .93144 \\
DV3 & Educational technology helps me to achieve the objective in my & 4.0381 & .97983 \\
& learning course & & \\
DV4 & I am comfortable using educational technology & 4.1048 & .98960 \\
DV5 & I would recommend this method to others & 4.1429 & .96505 \\
& Perceived student interaction through educational technology & 3.7010 & .82561 \\
PI1 & Interacting online with tutor/lecturer is easier & 3.7238 & .97562 \\
\hline
\end{tabular}




\begin{tabular}{|c|c|c|c|}
\hline & Questions & Mean & SD \\
\hline PI2 & Interacting with other student is easier & 3.7143 & 1.00684 \\
\hline PI3 & Class discussion is more efficient & 3.6952 & 95196 \\
\hline PI4 & It is easier to follow class discussion and updates & 3.8571 & .95503 \\
\hline \multirow[t]{2}{*}{ PI5 } & $\begin{array}{l}\text { Virtual interaction is more effective compared to classroom } \\
\text { interaction }\end{array}$ & 3.5143 & 1.00110 \\
\hline & Perceived usefulness and ease of use & 3.9448 & .79300 \\
\hline PU1 & $\begin{array}{l}\text { Using educational technology enhance the effectiveness in my } \\
\text { learning process }\end{array}$ & 3.9048 & .87182 \\
\hline PU2 & $\begin{array}{l}\text { Using educational technology improve my performance in my } \\
\text { learning process }\end{array}$ & 3.9524 & .88122 \\
\hline PU3 & Using educational technology enhance my productivity & 3.9524 & .84786 \\
\hline PU4 & $\begin{array}{l}\text { It would be easy for me to be skilful at using educational } \\
\text { technology }\end{array}$ & 3.9429 & .87518 \\
\hline \multirow[t]{2}{*}{ PU5 } & $\begin{array}{l}\text { I find educational technology easy to use and useful for my } \\
\text { learning process }\end{array}$ & 3.9714 & .85998 \\
\hline & Perceived flexibility using educational technology & 3.9486 & .80193 \\
\hline PF1 & $\begin{array}{l}\text { Using educational technology allowed me to arrange my task } \\
\text { schedule more effectively }\end{array}$ & 3.9619 & .88713 \\
\hline PF2 & $\begin{array}{l}\text { Using educational technology saved a lot of time commuting to } \\
\text { class }\end{array}$ & 3.8952 & .92947 \\
\hline PF3 & $\begin{array}{l}\text { Using educational technology allowed me to access information } \\
\text { anytime }\end{array}$ & 4.20000 & .91357 \\
\hline PF4 & $\begin{array}{l}\text { Using educational technology allowed me to take a class I would } \\
\text { otherwise have to miss }\end{array}$ & 3.8000 & .99421 \\
\hline \multirow[t]{2}{*}{ PF5 } & $\begin{array}{l}\text { Using educational technology allowed me to spend more time on } \\
\text { non-work-related activities }\end{array}$ & 3.8857 & .95388 \\
\hline & Perceived information quality using educational technology & 3.8286 & .81355 \\
\hline PQ1 & Information receive through educational technology is accurate & 3.8000 & .88143 \\
\hline PQ2 & Information available on search engines is helpful & 3.9333 & .94326 \\
\hline PQ3 & Information provided is reliable and correct & 3.7429 & .90966 \\
\hline PQ4 & $\begin{array}{l}\text { Information on educational technology is understandable and } \\
\text { concise }\end{array}$ & 3.7810 & .93006 \\
\hline PQ5 & Information on educational technology is the quality & 3.8857 & .95388 \\
\hline
\end{tabular}

Table 3: Model summary Predictors: (Constant), PQ, PF, PI, PU

\begin{tabular}{ccccc}
\hline Model & R & R Square & Adjusted R Square & Std. Error of the Estimate \\
\hline 1 & $.793^{\mathrm{a}}$ & .628 & .614 & .55327 \\
\hline
\end{tabular}

Table 4: The coefficients result between student's satisfaction and educational technology dimensions

\begin{tabular}{clccc}
\hline Hypothesis & \multicolumn{1}{c}{ Relationships } & $\begin{array}{c}\text { T } \\
\text { Values }\end{array}$ & $\begin{array}{c}\text { P } \\
\text { Values }\end{array}$ & Conclusion \\
\hline $\mathbf{H 1}$ & $\begin{array}{l}\text { Interactive educational technology-> } \\
\text { Student's satisfaction learning process }\end{array}$ & 3.105 & 0.002 & Significant \\
$\mathbf{H 2}$ & $\begin{array}{l}\text { Perceived usefulness -> Student's satisfaction } \\
\text { learning process }\end{array}$ & 2.903 & 0.005 & Significant \\
$\mathbf{H 3}$ & $\begin{array}{l}\text { Information quality -> Student's satisfaction } \\
\text { learning process } \\
\text { Educational technology flexibility-> Student's } \\
\text { satisfaction learning process }\end{array}$ & 0.585 & 0.560 & $\begin{array}{c}\text { Not } \\
\text { significant } \\
\text { Not }\end{array}$ \\
& significant \\
\hline
\end{tabular}


With reference to table 2, the relationship between Interactive educational technology and Student's satisfaction learning process is positive significant ( $\mathrm{t}$-value $=3.105, \mathrm{P}=0.002$ ). For second hypothesis, the relationship between student's satisfaction towards user's perceived usefulness and the student's satisfaction learning process is positive significant (t-value = $2.903, \mathrm{P}=0.005)$. The relationship between information quality and student's satisfaction learning process is not significant $(\mathrm{t}$-value $=0.585, \mathrm{P}=0.560)$. Lastly, the relationship between educational technology flexibility and student's satisfaction learning process is not significant (t-value $=1.069, \mathrm{P}=0.288$ ).

Table 5: The coefficients result between student's satisfaction and educational technology dimensions

\begin{tabular}{ccccc}
\hline Model & $\begin{array}{c}\text { Unstandardized Coefficients } \\
\text { (Beta) }\end{array}$ & $\begin{array}{c}\text { Standardized Coefficients } \\
\text { (Beta) }\end{array}$ & T Values & P Values \\
\hline (Constant) & .377 & & 1.277 & .204 \\
PI & .345 & .320 & 3.105 & .002 \\
PU & .422 & .376 & 2.903 & .005 \\
PF & .076 & .069 & .585 & .560 \\
\hline
\end{tabular}

Student's satisfaction using educational technology is important as it enhance student's learning process. The data descriptive by SPSS showing all the respondent's profile. The respondents are mostly degree students from IPTA and IPTS. The findings indicated that students used education technology for their learning process to find information through search engines is the major purpose. The second highest is attempting online quizzes, tests and forum. Followed by submitting assignment and tasks, virtual learning education (VLE), electronic campus information exchange (e-Citie), assessing tutorials, and checking updates and news. The least are editing, designing tools and interacting with students and tutor. From this, we can see that to find information through search engines is the most purpose for learning process. This is because, all the information they must find through the search engine due to more efficient and faster.

From the survey, the satisfaction using educational technology on learning process is when they are adapting and using it well. When they reach the demand, they will be satisfied with the learning process. Recommendation are made to other users due to the satisfaction earned while using the educational technology in learning process. It can be shown that educational technology helps to achieve the objective in learning with higher mean at 4.03. The data revealed that interactive educational technology and student's satisfaction on learning process are supported. It shows that using educational technology can be easier to follow class discussion and updates with higher mean at 3.85. However, virtual interaction is not effective compared to classroom interaction with stand mean at 3.51. They need to improve interaction synchronize with physical classroom. Moreover, the data collection on perceived usefulness and ease of use can be seen as significant. Students perceived higher satisfaction on the usefulness of educational technology. They find educational technology is easy to use and useful for their learning process with stand mean at 3.97. This is because through the platform, students are able to find retrieve information. The data revealed for perceived flexibility using educational technology have positive impact on the student's satisfaction using the educational technology to access information anytime with stand mean at 4.20. Hence, educational technology is flexible for students' learning process to access what their needs without hesitation. Data show for perceived information quality on students' satisfaction level is not supported due to insignificant mean. Besides, the data collected on perceived information quality by using educational technology with stand mean at 3.93 indicate that the information 
available on search engine is helpful. It is a positive impact that students are able to gather information using search engine such as, google scholar.

The analysis of relationships between the educational technology dimensions and student's satisfaction on learning process can be showed that interaction and usefulness and easy to use are positively significant. The hypothesis is accepted. Therefore, educational technology has been adapted onto student's learning process positively. However, the flexibility and information quality indicate no relationship and insignificant because the $\mathrm{P}$ Value is bigger than 0.05 even though the relationship is positive but weak. This is contradicted to research made by Al-Samarraie, Teng, Alzahrani, \& Alalwan, (2018), whereby information quality had the highest score among the core factors for e-learning continuance satisfaction in their study. Other than that, it can be improved by adding some dimension or improving the current dimension that can helps to gain better satisfaction on the learning process. As we can see that, information quality and flexibility were not significant due to no correlation. Information quality can be improved by ensuring the tutors or students are using the relevant information and syllabus that are standardized in virtual learning according to lessons that are being teach in traditional classroom. All the students should use reliable sources for their references. For flexibility, it can be seen that internet connection could be one of the restrictions for them to access the tools. It might be hard for them to use the technology if they did not have the internet connection. Thus, educational technology can be innovated into offline method to ensure the continuance usage.

\section{Conclusion}

In conclusion, for this research paper entitle the satisfaction level of educational technology on student's learning process, this research paper has revealed the dimensions that need to be measured on the satisfaction level on student's learning process towards educational technology. The result shows that the dimension of interactivity and usefulness are positively influence the level of satisfaction while flexibility and information quality indicate no relationships. Accessibility of the educational tools and accuracy of contents provided on educational technology can contribute to the significant level of satisfaction on student's learning process. Therefore, improvement such as time saving, providing understandable and concise information may indicate better influence on the student's satisfaction. From the research above, educational technology may help student's learning process since educational technology has been widely used among students to keep them up to date and create better performance. When it comes to efficiency aspect, tools that are convenience for students may support their learning process. As conclusion, educational technology has good relationship with students' learning process because, from the result computed, it can be seen that educational technology is more effective compared to traditional method. Everything is quicker and efficient by using this type of technology. It is time saving since the students can find answers by utilizing educational technology platform. 


\section{References}

[1] Y. J. Joo, K. Y. Lim, and S. M. Kim, "A Model for Predicting Learning Flow and Achievement in Corporate e-Learning," J. Educ. Technol. Soc., vol. 15, no. 1, pp. 313-325, 2012.

[2] M. Barak and Y. J. Dori, "Enhancing undergraduate students' chemistry understanding through project-based learning in an IT environment," Sci. Educ., vol. 89, no. 1, pp. 117-139, Jan. 2005.

[3] F. Alonso, G. Lopez, D. Manrique, and J. M. Vines, "An instructional model for web-based elearning education with a blended learning process approach," Br. J. Educ. Technol., vol. 36, no. 2, pp. 217-235, Mar. 2005.

[4] R. Yilmaz, "Exploring the role of e-learning readiness on student satisfaction and motivation in flipped classroom," Comput. Human Behav., vol. 70, pp. 251-260, May 2017.

[5] S.-S. Liaw and H.-M. Huang, "Perceived satisfaction, perceived usefulness and interactive learning environments as predictors to self-regulation in e-learning environments," Comput. Educ., vol. 60, no. 1, pp. 14-24, Jan. 2013.

[6] S. Ghavifekr and W. A. W. Rosdy, "Teaching and Learning with Technology: Effectiveness of ICT Integration in Schools," Int. J. Res. Educ. Sci., vol. 1, no. 2, p. 175, 2015.

[7] M. T. Al-Hariri and A. A. Al-Hattami, "Impact of students' use of technology on their learning achievements in physiology courses at the University of Dammam," J. Taibah Univ. Med. Sci., vol. 12, no. 1, pp. 1-4, Feb. 2016.

[8] J. Alexander, M. Barcellona, S. McLachlan, and C. Sackley, "Technology-enhanced learning in physiotherapy education: Student satisfaction and knowledge acquisition of entry-level students in the United Kingdom," Res. Learn. Technol., vol. 27, no. 2073, pp. 1-14, 2019.

[9] H. Al-Samarraie, B. K. Teng, A. I. Alzahrani, and N. Alalwan, "E-learning continuance satisfaction in higher education: a unified perspective from instructors and students," Stud. High. Educ., vol. 43, no. 11, pp. 2003-2019, Nov. 2018. 